\title{
COMPETITIVENESS OF UKRAINIAN EXPORT-ORIENTED FIELDS
}

\author{
Volodymyr Toryanyk' ${ }^{1}$, Vladimir Dzhyndzhoian², Yevhen Namliyev³ \\ Dnipro Humanitarian University, Ukraine
}

\begin{abstract}
The article presents the results of the study of the current state of competitiveness of the export-oriented industries of the Ukrainian economy. It shows that the level of engagement in international trade determines the international competitiveness of the national economy, its readiness and the ability to create developed competitive advantages. It is proved that in Ukraine today just a small number of branches of the economy are competitive in foreign markets as they offer raw materials or products with a low level of positive value to the countries abroad. Taking it into account, this research goal is to determine, which export-oriented industries deserve state support and which tools and methods should be used for this purpose. The methodological basis of the research was the general scientific methods of dialectics, observation, measurement and formalization; methods of the system, statistical and graphical analysis. In particular, to identify the export-oriented industries of the domestic economy, the methodology for calculating the index of identified competitive advantages was used. It is determined that the export-oriented branches of the domestic economy include: extractive industry, metallurgy, agriculture, food industry, and chemical industry. The calculations showed that among the 223 items, which were under the analysis, only for 47 of them these figures are greater than 1. This high indicator is mainly featured for commodity products. It is concluded that without reforming the structure of the domestic economy, there will be no significant changes in the national economy since the main items of export will continue to remain the raw materials and semi-finished products in terms of the unchanging nature of the specialization of the domestic business. It is substantiated that one of the directions of increasing the competitiveness of the domestic business is increasing both the production of the added value of high-tech industries (such as the chemical industry) and the export of intermediate and end products, in which it is embodied. It has been determined that changes in the sectoral structure are needed to increase non-raw added value created in the areas of the added value. Further research will be aimed at improving the mechanism of state support for export-oriented industries of Ukraine.
\end{abstract}

Key words: international trade, competitiveness, export-oriented industries, production with high added value.

JEL Classification: F40, L16, L60, P45

\section{Introduction}

An important place in the economic development of any country is taken by the international trade, which overcomes the limited resources and the narrowness of the domestic regional and national market, creates the possibility of mass production, increases the degree of equipment loading, increases the efficiency of the introduction of new technology, enlarges the accumulation, the pace of economic growth, and more rational use of resources of countries.

The development of international trade relations connects all countries of the world in one production chain, the operation of which causes the synchronization of economic cycles of all economies in the world. The level of engagement in international trade determines the international competitiveness of the national economy, its readiness and the ability to create developed competitive advantages (Duginets, 2017).

According to the results of the preliminary analysis, it should be noted that in Ukraine today only a small number of branches of the economy are competitive in foreign markets, and those industries that are exportoriented offer foreign raw materials or products with low added value. Such a commodity structure of exports makes the country vulnerable to external changes and calls into question the possibility of strengthening the competitive position in international markets, even if there are preferential agreements. All the above mentioned makes the chosen topic of the study relevant.

\footnotetext{
Corresponding author:

${ }^{1}$ Department of General Law Disciplines, Dnipro Humanitarian University.

E-mail: torikv66@gmail.com

${ }^{2}$ Department of Economics and Tourism Management, Dnipro Humanitarian University.

E-mail: dzhindzhojan@gmail.com

${ }^{3}$ Vocational Guidance and External Relations, Dnipro Humanitarian University.

E-mail: ev.namliev@i.ua
} 


\section{Review of theory and literature}

The analysis of recent studies suggests that the issue of international competitiveness of industries is a matter of exploration for a wide range of scholars (for example, Haldar, Rao, Momaya, 2016, and Juan, Su, 2014). In Ukraine, the works of Andryeyeva N., Zinkovska D. (2016), Byba V. (2017), Goryanska T. (2012), Duginets G. (2017), and Mazaraki A. (2016) are devoted to the determination of directions of increasing competitiveness of export-oriented industries in modern conditions. In addition, the relevance of the research problem is confirmed by numerous attempts to hold public hearings and meetings with the aim of identifying further joint actions of the authorities and business towards the implementation of EU requirements in order to increase the competitiveness of Ukrainian industries in the European market, as well as the work of scientific and non-governmental organizations. Despite the numerous scientific works devoted to the chosen research direction, the theoretical foundations and practical aspects of the given problem still need to be improved, especially taking into account the transformations of international trade. Thus, the purpose of the study is to determine which exportoriented industries deserve state support and which tools and methods should be used for this purpose.

\section{Data collection}

The theoretical and methodological basis of the research was the scientific works of leading Ukrainian and foreign scientists in the domains of international trade, enhancement of international competitiveness, as well as state regulation of these processes. As a result of the research, the general scientific methods of dialectics, observation, measurement, and formalization were used, as well as methods of the system and statistical analysis. In particular, to identify the export-oriented industries of the domestic economy, the methodology for calculating the index of identified competitive advantages was used. The analytical data of the United Nations Conference on Trade and Development (UNCTAD) and the State Statistics Committee of Ukraine became the information base for the approbation of the proposed approach.

\section{The theoretical and methodological basis of research}

An important place in the economic development of any country is taken by international trade, which overcomes the limited resources and the narrowness of the domestic regional and national market, creates the possibility of mass production, increases the degree of loading equipment, increases the efficiency of the introduction of new technology, enlarges the accumulation, the pace of economic growth, more rational use of countries' resources. The development of international trade relations connects all countries of the world in one production chain, the functioning of which causes the synchronization of economic cycles of all economies of the world.

The assessment of the competitiveness of economic entities of open economic systems is a complex multifactorial task, which comes to the interpretation and evaluation of a set of indicators characterizing various aspects of the enterprise activities that shape its competitiveness (Yokhna, 2017).

Today, many indicators have been developed that reflect the effects of using the factors of production of a particular industry in the defined period, forming its competitive advantages. These effects are determined by many factors that indicate the competitiveness of the industry, in particular, the volume and efficiency of labour, the volume and efficiency of real (property) capital, as well as the level and efficiency of the knowledge usage. The use of such indicators allows us to assess the economic situation of a specific branch of the economy. The most commonly used tool for empirical analysis of the country's foreign trade specialization and the assessment of advantages is the Revealed Comparative Advantage Index, which is called the Balassa Index $(1965 ; 1987)$ :

$$
B=X_{i j} / X_{r j} / X_{i s} / X_{r s}
$$

where $X_{i j}$ - the volume of export of goods (or commodity group) $i$ of the country $j$;

$X_{r j}$ - total export of the country $j$;

$X_{i s}$ - volumes of export of goods (or commodity group) $i$ by all countries of the world;

$X_{r s}$ - total world export.

This index indicates what is the ratio of the export share of the investigated industry in the total export of the analysed country to the share of industry's exports in the total volume of world exports (or in the union of countries, for example, the EU, CIS, etc.). If the index value is greater than 1 , the comparative advantage is considered to be detected, that is, the sector or industry as a whole is relatively more specialized in terms of exports. Studies show that according to the Balassa Index, the country's comparative advantage can be divided into a certain product (a group of goods) into four types (Table 1) (Balassa, 1965).

A relative comparative advantage can be defined both at the global level and at the regional or subregional levels or can be limited to analysing the trade between two countries.

\section{The approbation of the proposed approach}

The results of the analysis of foreign trade activity of Ukraine in 2012-2017 show that over the past two years exports have increased by $16.0 \%$, and imports - by $23.3 \%$. But in the wake of 2017, a negative balance of foreign trade balance was formed (-2625.4 million dollars) (Table 2). 
Table 1

Interpretation of comparative advantage

of the country in the products of the industry using the Balassa Index

\begin{tabular}{|c|l|}
\hline Index value & \multicolumn{1}{|c|}{ Content of index limits } \\
\hline $0<\mathrm{B} \leq 1$ & Lack of relative superiority in the export of industry's products \\
\hline $1<\mathrm{B} \leq 2$ & The weak comparative advantage in the export of industry's products \\
\hline $2<\mathrm{B} \leq 4$ & The significant comparative advantage in the export of industry's products \\
\hline $4<\mathrm{B}$ & A strong comparative advantage in the export of industry's products \\
\hline
\end{tabular}

Table 2

Geographical structure of foreign trade in goods and services of Ukraine in 2012-2017, million USD

\begin{tabular}{|l|c|c|c|c|c|c|}
\hline \multicolumn{1}{|c|}{ Countries/Year } & 2012 & 2013 & 2014 & 2015 & 2016 & 2017 \\
\hline Total Export & $\mathbf{8 0 8 9 5 , 8}$ & $\mathbf{7 4 8 3 2 , 3}$ & $\mathbf{6 4 1 0 6 , 8}$ & $\mathbf{4 6 8 0 4 , 2}$ & $\mathbf{4 5 1 1 2 , 7}$ & $\mathbf{5 2 3 2 9 , 6}$ \\
\hline Goods & 67779,8 & 62305,9 & 53901,7 & 38127,1 & 36362,8 & 43266,6 \\
\hline CIS Countries & 24911,3 & 21672,1 & 14882,3 & 7806,1 & 6030,5 & 6917,5 \\
\hline Other Countries & 25930,6 & 24060,3 & 22016,5 & 17305,8 & 16834,6 & 18814,6 \\
\hline EU Countries (28) & 16937,9 & 16573,5 & 17002,9 & 13015,2 & 13497,7 & 17534,5 \\
\hline Services & 13116 & 14233,2 & 11520,8 & 9736,6 & 9631,4 & 10446,6 \\
\hline CIS Countries & 5811,1 & 5814,9 & 4034,3 & 3544,8 & 3642,1 & 3737,7 \\
\hline EU Countries (28) & 3750,2 & 4195,7 & 3991,6 & 2927,9 & 2950,9 & 3379,3 \\
\hline Other Countries & 3554,7 & 4222,6 & 3494,9 & 3263,9 & 3038,4 & 3329,6 \\
\hline Total Import & $\mathbf{8 9 7 7 4 , 6}$ & $\mathbf{8 3 3 4 6 , 5}$ & $\mathbf{6 0 7 5 0 , 6}$ & $\mathbf{4 2 9 7 6 , 0}$ & $\mathbf{4 4 5 7 1 , 1}$ & $\mathbf{5 4 9 5 5 , 0}$ \\
\hline Goods & 83135,4 & 75834,6 & 54428,7 & 37516,4 & 39248,6 & 49598,5 \\
\hline CIS Countries & 34317,9 & 27741,5 & 17276,9 & 10485,5 & 8563,8 & 11475,6 \\
\hline EU Countries (28) & 26033,9 & 26766,9 & 21069,1 & 15330,2 & 17138,2 & 17321,1 \\
\hline Other Countries & 22783,6 & 21326,2 & 16082,7 & 11700,7 & 13546,6 & 20795,8 \\
\hline Services & 6639,2 & 7523 & 6373,1 & 5523 & 5304,7 & 5359,2 \\
\hline CIS Countries & 1238,2 & 1466,5 & 1204 & 839,6 & 824,5 & 639,4 \\
\hline EU Countries (28) & 3641,2 & 4212 & 3148,8 & 2750,1 & 2336,7 & 2503,0 \\
\hline Other Countries & 1759,8 & 1844,5 & 2020,3 & 1933,3 & 2143,5 & 2216,8 \\
\hline
\end{tabular}

${ }^{*}$ To avoid double counting, the total volume of goods and services is calculated according to the formula: total (goods and services) $=$ goods + services the cost of services for the processing of goods for the purpose of selling abroad

Source: compiled by the authors according to the State Statistics Service of Ukraine

So, as it can be seen from the above data, in spite of certain difficulties and a significant drop in volumes of trade, in the last two years, there is a positive trend of development. It should also be noted that according to the State Statistics Service in the past two years, the largest volumes of exports are raw materials, and imports are high-tech goods and complex chemical compounds (Table 3 ).

Such a commodity structure of export-import operations is an indicator of the dependence of the foreign trade sphere of Ukraine on changes in the external environment. The complex socio-political conditions over the last 4 years have led to deformation in the characteristics of concentration and diversification of the Ukrainian exports. So, for a long time, import remains much more advanced and wider than the Ukrainian export. The transformation of the geographic structure of exports from the CIS to the EU has led to a reduction in the market for high value-added products and an increase in the supply of raw materials and low-grade products. The above makes it possible to state that for Ukraine the issue of increasing the competitiveness of export-oriented industries is a strategically important task.
In order to identify the export-oriented industries of the domestic economy, we have calculated the index of the identified competitive advantages of Ukraine. The calculations carried out according to UNCTAD (2017) showed that among 223 items for which the calculations were made, for only 47 this figure is greater than 1 . This high indicator is mainly presented for raw materials (primary ingots from iron - 68.4, barley 43.28 , corn feed -42.84 , eggs -13.52 , vegetable fats 41.4), while for finished products the coefficient still remains low (fruit juices -5.02 , chocolate and sweets 3.04, tobacco products -3.9 ) (Table 4). This situation indicates that without reforming the structure of the domestic economy, there will be no significant changes in the national economy, as under the non-change of the specialization of domestic business, the main items of export will continue to remain the raw materials and semi-finished products.

According to the results of the calculations, the export-oriented industries of the domestic economy include: extractive industry, metallurgy, agriculture, food industry, and chemical industry (see Table 4). 
Table 3

The main commodity groups of Ukrainian exports and imports to Ukraine in 2016-2017*

\begin{tabular}{|l|l|c|c|c|c|}
\hline \multicolumn{2}{|c|}{$\begin{array}{c}\text { Code and name of the goods according } \\
\text { to UKTZED }\end{array}$} & US thousand dollars & $\begin{array}{c}\text { in \% to the total } \\
\text { volume }\end{array}$ & US thousand dollars & $\begin{array}{c}\text { in to the total } \\
\text { volume }\end{array}$ \\
\hline II. Products of vegetable origin & 8093693,7 & 22,3 & 1284816,5 & 3,3 \\
\hline $\begin{array}{l}\text { III. Fats and oils of animal or vegetable } \\
\text { origin }\end{array}$ & 3962975,8 & 10,9 & 245957,3 & 0,6 \\
\hline V. Mineral products & 2728764,8 & 7,5 & 8495024,4 & 21,6 \\
\hline $\begin{array}{l}\text { VI. Production of chemical and } \\
\text { related industries }\end{array}$ & 1558173,2 & 4,3 & 5619505,4 & 14,3 \\
\hline $\begin{array}{l}\text { XV. Non-precious metals and goods } \\
\text { made of them }\end{array}$ & 8338854,6 & 22,9 & 2306476,1 & 5,9 \\
\hline $\begin{array}{l}\text { XVI. Machines, equipment and } \\
\text { mechanisms; electrical equipment }\end{array}$ & 3637946 & 10 & 7889365,2 & 20,1 \\
\hline Total & $\mathbf{3 6 3 6 1 7 1 1 , 2}$ & $\mathbf{1 0 0}$ & $\mathbf{3 9 2 4 9 7 9 7 , 2}$ & $\mathbf{1 0 0}$ \\
\hline II. Products of vegetable origin & 9215790,5 & 21,3 & 1388759,3 & 2,8 \\
\hline $\begin{array}{l}\text { III. Fats and oils of animal or vegetable } \\
\text { origin }\end{array}$ & 4586261,9 & 10,6 & 247992,7 & 0,5 \\
\hline V. Mineral products & 3937262,6 & 9,1 & 12498833,5 & 25,2 \\
\hline $\begin{array}{l}\text { VI. Production of chemical and } \\
\text { related industries }\end{array}$ & 1644131,6 & 3,8 & 6547008,0 & 13,2 \\
\hline $\begin{array}{l}\text { XV. Non-precious metals and goods } \\
\text { made of them }\end{array}$ & 10124389,6 & 23,4 & 3025511,2 & 6,1 \\
\hline $\begin{array}{l}\text { XVI. Machines, equipment and } \\
\text { mechanisms; electrical equipment }\end{array}$ & 4283395,6 & 9,9 & 9919709,1 & 20,0 \\
\hline \multicolumn{1}{|c|}{ Total } & $\mathbf{4 3 2 6 6 6 2 2 , 3}$ & $\mathbf{1 0 0}$ & $\mathbf{4 9 5 9 8 5 4 5 , 6}$ & $\mathbf{1 0 0}$ \\
\hline
\end{tabular}

* data for 2016-2017 are given without taking into account the temporarily occupied territory of the Autonomous Republic of Crimea, the city of Sevastopol, and parts of the zone of the anti-terrorist operation.

Source: compiled by the authors according to the State Statistics Service of Ukraine

Table 4

Competitive advantages of export-oriented industries of the Ukrainian economy

\begin{tabular}{|c|c|c|}
\hline $\begin{array}{l}\text { Industry (share in exports, } \\
\% \text { ) }\end{array}$ & $\begin{array}{l}\text { Index of comparative advantages } \\
\text { over major export items }\end{array}$ & Competitiveness factors \\
\hline Mining industry (4.7) & $\begin{array}{l}\text { Stone, gravel, sand }-4.66 \text {, iron ore and } \\
\text { concentrates }-11.43 \text {, aluminium ore }-5.98\end{array}$ & Availability of natural resources. \\
\hline Metallurgy industry (27.8) & $\begin{array}{l}\text { Ingots, primary forms of iron or steel; semi- } \\
\text { finished products - } 68.4\end{array}$ & $\begin{array}{l}\text { Availability of natural resources. Due to inefficient } \\
\text { modernization, production is energy-intensive. The vast } \\
\text { majority of enterprises produce products with a small } \\
\text { degree of processing. }\end{array}$ \\
\hline Agriculture (19.7) & $\begin{array}{l}\text { Butter and other fats derived from milk }-1.42 \text {, } \\
\text { eggs }-13.52 \text {, wheat }-22.15 \text {, barley }-43.28 \text {, } \\
\text { corn }-42.84 \text {, other cereals }-6.78 \text {, tobacco } \\
\text { products }-3.9 \text {, animal feeds }-5.14 \text {, oil seeds - } \\
2.85 \text {, vegetable oils and oils purified }-41.4\end{array}$ & $\begin{array}{l}\text { Availability of natural resources, as well as long traditions } \\
\text { of agriculture; a large part of the population lives in } \\
\text { the countryside, is engaged in agriculture and is the } \\
\text { supplier of agricultural raw materials for large agricultural } \\
\text { enterprises. }\end{array}$ \\
\hline Food industry (5.1) & $\begin{array}{l}\text { Fruit juices - 5.02, chocolate } \\
\text { and confectionery - } 3.04\end{array}$ & $\begin{array}{l}\text { Availability of the raw material base, sufficiently high } \\
\text { quality, high internal competitiveness, which allows } \\
\text { enterprises to accumulate resources for development. }\end{array}$ \\
\hline Chemical industry (7) & Inorganic chemical elements -3.53 & $\begin{array}{l}\text { The presence of skilled personnel, as well as research } \\
\text { institutes and enterprises. }\end{array}$ \\
\hline
\end{tabular}

Source: calculated according to UNCTAD (2017)

At the same time, the main factors affecting the export position of these industries are the availability of natural resources in the country, which allows for producing products of high quality at lower prices than competitors.
Competitiveness of goods and services traditionally consists of two components: qualitative and price. In fact, the success of the competition is achieved by those enterprises that are able to offer consumers 
products that fully meet the requirements for a reasonable price, which, in turn, should provide the company with income sufficient to cover its costs and invest in further development. As it can be seen from the table presented, for most of the export-oriented industries, Ukraine today mainly has price competitive advantages that arise as a result of the country's resource and geographical preconditions for production.

However, the potential of these industries is not fully exploited. For example, in Ukraine, there are all conditions for ensuring organic food production with high-quality, environmentally friendly raw materials at the expense of existing balanced and organic agriculture, which is characterized by low levels of pesticides and chemical fertilizers, a sufficient number of small farms and skilled labour.

One of the reasons for the relatively low competitiveness of exports is that Ukraine is at a lower level of technological development than developed countries. That can be confirmed by the growing dependence of Ukrainian machine building on the import of high-tech products - both end-use and component products used in the compilation of machines of well-known foreign brands. Overcoming technological backwardness will help to create, with the obligatory support of the state, innovation parks and clusters. That, in turn, will allow us to reach the new level of Ukrainian exports - the export of goods with high added value. It is also theoretically possible to transfer some European productions to Ukraine because of the relatively low cost of labour. However, in practice, this is almost non-existent due to the risks of non-return of investments, taking into account the current state of affairs in the Ukrainian economy. An alternative to attracting FDI may be a strategy of supporting the domestic business by creating conditions for withdrawal from the "shadow" of the equity of Ukrainian enterprises.

One more problem of low competitiveness is the orientation of those producers who offer high-quality raw materials for export. As a result, domestic finished products are produced using imported raw materials that are not always high quality, given that Ukrainian producers are trying to find the cheapest sources of supply, while high-quality raw materials that could be used to produce one hundred percent domestic products are exported abroad.

In general, the problems that are currently faced by the export-oriented industries of Ukraine are systemic. Their core cause is the lack of reforms that would allow the industrial complex of the country to develop in accordance with the requirements of the modern market. The existing state competition policy is fragmented, the priorities of state support and the ways of its provision are not defined. Lending resources received abroad are used to finance social needs rather than for economic development, which is reflected in low competitiveness indices of domestic industries. Thus, given the weak support of the government and the lack of initiative of the business, one can expect only a deterioration of the situation for domestic producers, since the abolition of import duties for European goods will give the foreign supplier the opportunity to increase the price competitiveness component in the Ukrainian market, which is one of the factors of the growth of imports in recent years.

\section{Conclusions}

To sum it up, it should be noted that today the most competitive domestic products in foreign markets are products of the raw materials sectors of the economy, which indicates significant disparities in the domestic economy compared with countries that are world technological and economic leaders. The analysis made it possible to find that the main problems of low competitiveness are energy dependence, underdevelopment of infrastructure, and the lack of a well-balanced state policy to support export-oriented industries. At the same time, it is necessary to take into account that actions of the state alone cannot provide a positive influence on the competitive position of the domestic business. Enterprises, acting as the main subjects of international relations, should be actively involved in the process, searching for foreign partners and adapting products to the requirements of international markets. Therefore, among the main directions of increasing the competitiveness of enterprises of export-oriented industries, we note:

- the development of vertical integration associations that will give manufacturers such competitive advantages as minimizing the dependence on suppliers, eliminating fluctuations in prices for raw materials. The closed cycle of production of these structures includes the cultivation, storage, and processing of raw materials for the production and sale of finished products. Thus, there is cost savings, efficient management of resources and information flows.

- an increase both in the production of added value in high-tech sectors and in the export of intermediate and final goods, in which it is embodied. It is primarily about the need to increase non-raw added value, that is, the added value of high-tech industries such as the chemical industry. This is due to both the need to change the sectoral structure of the economy and the change in the structure created in the areas of the added value.

Given that the full participation of Ukrainian producers in international competition is still far away, at this stage, an important task is to maintain existing positions in the international market, which, under the current conditions of development of the country, may be in jeopardy. Therefore, further research will be aimed at improving the mechanism of state support for export-oriented industries of Ukraine. 


\section{References:}

Andryeyeva N., Zinkovska D. (2016). Implementing the EU norms and standards in the agricultural industry Ukraine in the increase its international competitiveness. Naukovyy visnyk Odeskoho natsionalnoho ekonomichnoho universytetu [Scientific Herald of the Odessa National Economic University]. 3(235), 5-22.

Byba V. (2017). Competitiveness of Ukrainian Agricultural Enterprises on the International markets. Ekonomika i rehion: naukovyy visnyk PoltNTU im. Yuriya Kondratyuka [Economics and region: scientific journal PoltNTU them. Yuri Kondratyuk]. 1(62), 95.

Balassa B. (1965). Trade Liberalization and 'Revealed Comparative Advantage. The Manchester School. No. 33, 99-123.

Balassa B., Bauwens L. (1987) Intra-industry specialisation in a multi-country and multi-industry framework. Economic Journal. Vol. 97, 923-939.

Duginets G. (2017). Transformation of Ukrainian foreign trade flows in the context of Ukraine-EU association. Zhurnal ievropejskoi ekonomiky [Journal of the European Economy], 16(3), 317-329.

Goryanska T. (2012). Competitive positions of the export-oriented sectors of the Ukrainian economy. Economy of industry, (1-2), 57-58. Retrieved from: http://nbuv.gov.ua/j-pdf/econpr_2012_1-2_19.pdf

Haldar A., Rao S.N., Momaya K.S. (2016). Can flexibility in corporate governance enhance international competitiveness? Evidence from Knowledge-Based Industries in India. Global Journal of Flexible Systems Management, 17(4), 389-402.

Mazaraki A. (2016). Foreign Trade of Ukraine: XXI Century: Monograph. Kyiv: KNTEU. (in Ukrainian)

Juan H., Su L. (2014). The Comparative Research on International Competitiveness of Service Industry between Mainland China and Taiwan. Taiwan Research Journal, 2, 010.

State Statistics Service of Ukraine. Retrieved from: http://www.ukrstat.gov.ua/ (in Ukrainian)

Yokhna M. (2017). Conceptual model of business entities evolution in competition environment. Visnyk Khmelnytskoho natsionalnoho universytetu. Ekonomichni nauky [Bulletin of the Khmelnytsky National University. Economic sciences]. 2(2), 7-11.

UNCTAD (2017). UNCTADstat. Retrieved from: http://unctadstat.unctad.org 